Vol. 19 No. 12019

e-issn : 2622-6960, p-issn : 0854-624X

\title{
HUBUNGAN HIGIENE SANITASI DENGAN KANDUNGAN BAKTERIOLOGIS PADA MINUMAN YANG DIJUAL DI SEPANJANG PANTAI LOSARI Inayah $^{1}$ dan Sri Reski Astuti ${ }^{2}$ \\ 1.2Jurusan Kesehatan Lingkungan Poltekkes Kemenkes Makassar \\ Inayahmahmud.500@gmail.com
}

\begin{abstract}
Food and beverages traded by street vendors in the processing process often pay less attention to sanitary hygiene factors so that the potential for biological contamination causes digestive infections. The purpose of this study was to determine the relationship of sanitation hygiene with bacteriological content in drinks sold along Losari Beach. The type of this research is quantitative research using an observational method with a cross-sectional approach where the independent variables and the dependent variable are compared together to determine the relationship between these variables. The results of this study indicate that there is a relationship between hand hygiene and bacteriological content $(p=0.011 C C=0.41)$. There is a relationship between equipment cleanliness and bacteriological content $(p=0.00 C C=0.64)$. There is a relationship between sanitation of beverage processing facilities with bacteriological content $(p=0.00 \mathrm{CC}=0.665)$ and there is a relationship between sanitation of material storage with bacteriological content $(p=0.00 \mathrm{CC}=0.687)$. The conclusion in this study is that there is a relationship between hand hygiene, cleanliness of equipment, sanitation of beverage processing facilities, and sanitation of the storage of materials with bacteriological content. The suggestion for traders is to pay more attention to sanitation hygiene when processing a beverage. Food and beverages traded by street vendors in the processing process often pay less attention to sanitary hygiene factors so that the potential for biological contamination causes digestive infections. The conclusion in this study is that there is a relationship between hand hygiene, cleanliness of equipment, sanitation of beverage processing facilities, and sanitation of the storage of materials with bacteriological content. Suggestion for traders is to pay more attention to sanitation hygiene when processing a beverage.
\end{abstract}

Keywords: Handler Hygiene, Beverage Sanitation, Bacteriological Content.

\section{ABSTRAK}

Makanan dan minuman yang diperjualbelikan oleh pedagang kaki lima dalam proses pengolahannya sering kali kurang memperhatikan faktor higiene sanitasi sehingga berpotensi terjadinya cemaran biologi penyebab infeksi pencernaan. Tujuan dari penelitian ini adalah untuk mengetahui hubungan hygiene sanitasi dengan kandungan bakteriologis pada minuman yang dijual disepanjang Pantai Losari. Adapun jenis penelitian ini yaitu penelitian kuantitatif menggunakan metode observasional dengan pendekatan cross sectional dimana variable bebas dan variable terikat dibandingkan secara bersamaan guna mengetahui hubungan antara variabel-variabel tersebut. Hasil penelitian ini menunjukkan bahwa ada hubungan higiene penjamah dengan kandungan bakteriologis ( $p=0,011 \quad C C=0,41)$. Ada hubungan kebersihan peralatan dengan kandungan bakteriologis ( $p=0,00$ $\mathrm{CC}=0,64)$. Ada hubungan sanitasi tempat pengolahan minuman dengan kandungan bakteriologis $(p=0,00 \mathrm{CC}=0,665)$ dan ada hubungan sanitasi penyimpanan bahan dengan kandungan bakteriologis $(p=0,00 \quad C C=0,687$ ). Kesimpulan dalam penelitian ini adalah ada hubungan antara higiene penjamah, kebersihan peralatan, sanitasi tempat pengolahan minuman, dan sanitasi penyimpanan bahan dengan kandungan bakteriologis. Saran bagi pedagang yaitu hendaknya lebih memperhatikan higiene sanitasi pada saat proses pengolahan minuman. Makanan dan minuman yang diperjualbelikan oleh pedagang kaki lima dalam proses pengolahannya sering kali kurang memperhatikan faktor higiene sanitasi sehingga berpotensi terjadinya cemaran biologi penyebab infeksi pencernaan. Kesimpulan dalam penelitian ini adalah ada hubungan antara higiene penjamah, kebersihan peralatan, sanitasi tempat pengolahan minuman, dan sanitasi penyimpanan bahan dengan kandungan bakteriologis. Saran bagi pedagang yaitu hendaknya lebih memperhatikan higiene sanitasi pada saat proses pengolahan minuman.

Kata kunci:Higiene Penjamah, Sanitasi Minuman, Kandungan Bakteriologis.

\section{Pendahuluan}

Di era sekarang ini, kebutuhan masyarakat terhadap makanan dan minuman yang disediakan di luar rumah semakin meningkat, contohnya saja adanya tempat - tempat umum yang menyediakan berbagai macam jenis makanan dan minuman yang sangat digemari masyarakat makadari itu produk-produk yang disediakanolehperusahaanatauperorangan yang bergerakdalam usaha penyediaan makanan dan minuman untuk kepentingan umum haruslah terjamin kesehatan dan keselamatannya yang telah ditetapkan pada Keputusan Menteri Kesehatan Republik Indonesia (KepmenkesRI) No. 942/Menkes/SK/VII/2003 tentangpedoman persyaratan higiene sanitasi makanan
jajanan.Pantai losari merupakan salah satu tempat - tempat umum yang memilikibanyak pedagang kaki lima yangmenawarkan berbagai macam makanan dan minumanjajanan

Penelitian Djaja (2008) mengenai tempat pengolahan makanan (TPM) didapatkan hasil jika TPM terbukti berpengaruh terhadap kontaminasi makanan, PKL berisiko 4,92 kali dibandingkan jasaboga, sedangkan berdasarkan jenis makanan yang disajikan PKL memiliki resiko 3,50 kali, restoran dan rumah makan 3,25 kali dibandingkan jasaboga 
Jurnal Sulolipu : Media Komunikasi Sivitas Akademika dan Masyarakat

Vol. 19 No.12019

e-issn : 2622-6960, p-issn : 0854-624X

\section{Bahan dan Metode}

\section{Lokasi Penelitian:}

Lokasi pengambilan sampel jus buah dilakukan di sepanjang Pantai Losari Kota Makassar, pemeriksaan kandungan bakteriologis adalah di Laboratorium Mikrobiologi Jurusan Kesehatan Lingkungan Politeknik Kesehatan Makassar.

2. Desain dan Variabel Penelitian

Jenis penelitian yang digunakan adalah penelitian kuantitatif menggunakan metode observasional dengan pendekatan cross sectional dimana variable bebas dan variable terikat dibandingkan secara bersamaan guna mengetahui hubungan antara variabel variable tersebut.

Adapun variabel bebas dalam penelitian ini yaitu higiene penjamah, kebersihan peralatan, tempat pengolahan minuman, dan penyimpanan bahan. Dan variabel terikat adalah kandungan bakteriologis (bakteri Coliform) pada minuman (jus buah).

\section{Sampel}

Adapun besarnya sampel dalam penelitian ini sebayak 50 pedagang.

\section{Pengumpulan data}

\section{a. Data Primer}

Data primer diperoleh dari hasil observasi langsung dan wawancara menggunakan lembar kuesioner dan lembar check list serta hasil pemeriksaan bakteri Coliform.

\section{b. Data Sekunder}

Data sekunder diperoleh melalui penelusuran kepustakaan berupa referensi hasil penelitian sebelumnya, jurnal, artikel, maupun laporan pemerintah.

\section{Analisa Data}

\section{a. Analisis satu variabel (univariate)}

Analisis univariate dilakukan untuk mendeskripsikan variable bebas yaitu: hygiene penjamah, kebersihan peralatan, tempat pengolahan minuman dan penyimpanan bahan dalam bentuk prosentase.

\section{b. Analisis dua variabel (bivariate)}

Analisis bivariate dilakukan terhadap dua variabel yang diduga berhubungan. Analisis ini menggunakan uji statistik dengan program Statistic Product and Service Solutions (SPSS) berupa Uji chi -square guna mengetahui hubungan antara hygiene sanitasi dan kandungan bakteri Coliform pada minuman yang dijual di sepanjang Pantai Losari

\section{Hasil Penelitian}

Berdasarkan hasil pemeriksaan di laboratorium didapatkan hasil penelitian sebagai berikut :

1. Higiene Penjamah Dengan Kandungan Bakteriologis

Tabel 1

Hubungan Higiene Penjamah Dengan Kandungan Bakteriologis Pada Minuman Yang Dijual Di Sepanjang Pantai Losari

\begin{tabular}{|c|c|c|c|c|c|c|c|c|c|}
\hline \multirow{3}{*}{$\begin{array}{l}\text { Higiene } \\
\text { Penjamah }\end{array}$} & \multicolumn{6}{|c|}{ Kandungan bakteri coliform } & \multirow{3}{*}{$\alpha$} & \multirow{3}{*}{$\mathbf{P}$} & \multirow{3}{*}{$\mathrm{CC}$} \\
\hline & \multicolumn{2}{|c|}{$\begin{array}{l}\text { Tidak } \\
\text { Ada }\end{array}$} & \multicolumn{2}{|c|}{ Ada } & \multirow{2}{*}{ Total } & \multirow{2}{*}{$\%$} & & & \\
\hline & $\Sigma$ & $\%$ & $\Sigma$ & $\%$ & & & & & \\
\hline $\begin{array}{l}\text { Tidak } \\
\text { Memenuhi } \\
\text { Syarat }\end{array}$ & 9 & 19 & 38 & 81 & 47 & 100 & & & \\
\hline $\begin{array}{l}\text { Memenuhi } \\
\text { Syarat }\end{array}$ & 3 & 100 & 0 & 0 & 3 & 100 & 0,1 & 0 & 0,4 \\
\hline total & 12 & 24 & 38 & 76 & 50 & 100 & & & \\
\hline
\end{tabular}

2. Hubungan Kebersihan Peralatan Dengan Kandungan Bakteriologis

Tabel 2

Hubungan Kebersihan Peralatan Dengan Kandungan Bakteriologis Pada Minuman Yang Dijual Di Sepanjang Pantai Losari

\begin{tabular}{|c|c|c|c|c|c|c|c|c|c|}
\hline \multirow{3}{*}{$\begin{array}{l}\text { Kebersi } \\
\text { han } \\
\text { Peralat } \\
\text { an }\end{array}$} & \multicolumn{6}{|c|}{ Kandungan bakteri coliform } & \multirow{3}{*}{$\alpha$} & \multirow{3}{*}{$p$} & \multirow{3}{*}{$\mathrm{CC}$} \\
\hline & \multicolumn{2}{|c|}{ Tidak Ada } & \multicolumn{2}{|c|}{ Ada } & \multirow{2}{*}{$\begin{array}{c}\text { Tot } \\
\text { al }\end{array}$} & \multirow{2}{*}{$\%$} & & & \\
\hline & $\Sigma$ & $\%$ & $\Sigma$ & $\%$ & & & & & \\
\hline $\begin{array}{l}\text { Tidak } \\
\text { Memen } \\
\text { uhi } \\
\text { Syarat }\end{array}$ & 2 & 5,1 & 37 & 95 & 39 & 100 & & & \\
\hline $\begin{array}{c}\text { Memen } \\
\text { uhi } \\
\text { Syarat }\end{array}$ & 10 & 91 & 1 & 9,1 & 11 & 100 & 0,1 & 0 & 0,6 \\
\hline Total & 12 & 24 & 38 & 76 & 50 & 100 & & & \\
\hline
\end{tabular}


Jurnal Sulolipu : Media Komunikasi Sivitas Akademika dan Masyarakat

Vol. 19 No.12019

e-issn : 2622-6960, p-issn : 0854-624X

3. Hubungan Sanitasi Tempat Pengolahan Minuman (TPM) Dengan Kandungan Bakteriologis

Tabel 3

Hubungan Sanitasi Tempat Pengolahan Minuman (TPM) Dengan Kandungan Bakteriologis Pada Minuman Yang Dijual Di Sepanjang Pantai Losari

\begin{tabular}{|c|c|c|c|c|c|c|c|c|c|}
\hline \multirow{3}{*}{$\begin{array}{l}\text { Sanita } \\
\text { si TPM }\end{array}$} & \multicolumn{6}{|c|}{ Kandungan bakteri coliform } & \multirow{3}{*}{$\alpha$} & \multirow{3}{*}{$\mathrm{P}$} & \multirow{3}{*}{$\mathrm{CC}$} \\
\hline & \multicolumn{2}{|c|}{$\begin{array}{c}\text { Tidak } \\
\text { Ada }\end{array}$} & \multicolumn{2}{|c|}{ Ada } & \multirow{2}{*}{$\begin{array}{l}\text { To } \\
\text { tal }\end{array}$} & \multirow{2}{*}{$\%$} & & & \\
\hline & $\Sigma$ & $\%$ & $\Sigma$ & $\%$ & & & & & \\
\hline $\begin{array}{c}\text { Tidak } \\
\text { Meme } \\
\text { nuhi } \\
\text { Syarat }\end{array}$ & 2 & 5 & 38 & 95 & 40 & $\begin{array}{l}10 \\
0\end{array}$ & & & \\
\hline $\begin{array}{c}\text { Meme } \\
\text { nuhi } \\
\text { Syarat }\end{array}$ & 10 & $\begin{array}{c}10 \\
0\end{array}$ & 0 & 0 & 10 & $\begin{array}{l}10 \\
0\end{array}$ & 0,1 & 0 & 0,7 \\
\hline Total & 12 & 24 & 38 & 76 & 50 & $\begin{array}{l}10 \\
0\end{array}$ & & & \\
\hline
\end{tabular}

4. Hubungan Sanitasi Penyimpanan Bahan Dengan Kandungan Bakteriologis

Tabel 4

Hubungan Sanitasi Penyimpanan Bahan Dengan Kandungan Bakteriologis Pada Minuman Yang Dijual Di SepanjangPantaiLosari

\begin{tabular}{|c|c|c|c|c|c|c|c|c|c|}
\hline \multirow{3}{*}{$\begin{array}{c}\text { Sanitasi } \\
\text { Penyimpa } \\
\text { nanBahan }\end{array}$} & \multicolumn{6}{|c|}{ Kandungan bakteri coliform } & \multirow{3}{*}{$\alpha$} & \multirow{3}{*}{$\mathrm{P}$} & \multirow{3}{*}{$\mathrm{CC}$} \\
\hline & \multicolumn{2}{|c|}{ Tidak Ada } & \multicolumn{2}{|c|}{ Ada } & \multirow{2}{*}{$\begin{array}{c}\text { Tot } \\
\text { al }\end{array}$} & \multirow{2}{*}{$\%$} & & & \\
\hline & $\Sigma$ & $\%$ & $\Sigma$ & $\%$ & & & & & \\
\hline $\begin{array}{l}\text { Tidak } \\
\text { Memenuh } \\
\text { i Syarat }\end{array}$ & 1 & 2,6 & 38 & 97 & 39 & $\begin{array}{c}10 \\
0\end{array}$ & & & \\
\hline $\begin{array}{l}\text { Memenuh } \\
\text { i Syarat }\end{array}$ & 11 & $\begin{array}{c}10 \\
0\end{array}$ & 0 & 0 & 11 & $\begin{array}{c}10 \\
0\end{array}$ & 0,1 & 0 & 0,7 \\
\hline Total & 12 & 24 & 38 & 76 & 50 & $\begin{array}{c}10 \\
0\end{array}$ & & & \\
\hline
\end{tabular}

\section{Pembahasan}

1. Higiene Penjamah Dengan Kandungan Bakteriologis

Pedagang kaki lima yang menggunakan penutup mulut saat bekerja hanya 3 pedagang ( $6 \%$ ), dan sebanyak 32 pedagang ( $64 \%$ ) yang mengobrol saat bekerja. Apabila tidak menggunakan penutup mulut dan mengobrol saat bekerja dapat mengakibatkan perpindahan mikroba dari mulut ke jus buah secara langsung melalui alat pernafasan. Untuk menghindari hal tersebut, dianjurkan bagi pedagang hendaknya menggunakan masker atau penutup mulut pada saat mengolah makanan dan minuman.

Kebersihan penjamah merupakan kunci dalam pengolahan makanan dan minuman yang aman dan sehat. Dengan demikian, penjamah makanan harus mengikuti prosedur yang memadai untuk mencegah kontaminasi pada makanan dan minuman yang ditanganinya. Prosedur yang penting bagi pekerja pengolahan makanan dan minuman adalah pencucian tangan, kebersihan dan kesehatan diri.

2. Hubungan Kebersihan Peralatan Dengan Kandungan Bakteriologis

Berdasarkan Keputusan Menteri Kesehatan RI no 942 tahun 2003 tentang pedoman persyaratan higiene sanitasi makanan dan minuman, menyatakan bahwa peralatan yang digunakan untuk mengolah dan menyajikan makanan dan minuman harus sesuai dengan peruntukannya dan memenuhi persyaratan higiene sanitasi, diantaranya peralatan yang sudah dipakai, dicuci dengan air bersih dan dengan sabun, lalu dikeringkan dengan alat pengering / lap yang bersih kemudian peralatan yang sudah bersih tersebut disimpan ditempat yang bebas pencemaran.

Berdasarkan 5 item pertanyaan mengenai kebersihan peralatan didapatkan hasil $62 \%$, $50 \%, 70 \%$, peralatan hanya dibilas / tidak dicuci, mencuci tidak menggunakan sabun atau sejenisnya serta tidak dikeringkan dengan lap / serbet bersih tetapi hanya ditiriskan dan $58 \%$ peralatan yang digunakan tidak disimpan di tempat yang bersih dan bebas dari pencemaran. Peralatan yang digunakan dalam proses pengolahan makanan / minuman apabila tidak dijaga kebersihannya dapat menimbulkan adanya kontaminasi silang antara peralatan dengan makanan / minuman, sehingga dapat ditemukannya bakteri penyebab penyakit didalam makanan / minuman yang disajikan.

3. Hubungan Sanitasi Tempat Pengolahan Minuman (TPM) Dengan Kandungan Bakteriologis

Hasil penelitian yang telah dilakukan dimana didapatkan $74 \%$ tempat penjualan jus berada di jalan yang ramai dengan arus kendaraan kecepatan tinggi sehingga 
Jurnal Sulolipu : Media Komunikasi Sivitas Akademika dan Masyarakat

Vol. 19 No.12019

e-issn : 2622-6960, p-issn : 0854-624X

memungkinkan adanya pencemaran dari udara, $56 \%$ memiliki tempat sampah tetapi tidak layak karena jaraknya dekat dengan tempat penjualan dan dalam keadaan terbuka sehingga memungkinkan adanya vektor pembawa penyakit seperti lalat yang hinggap dan membawa mikroba ke minuman hasil olahan, dan juga ditemukan $54 \%$ tempat pembuatan jus tercemar dari bahan pencemar makanan seperti sisa - sisa jus buah terlihat berserakan dan tidak dibuang di tempat sampah, peralatan pengolahan jus seperti mixer yang masih mengandung sisa sisa jus dibiarkan begitu saja, sehingga memungkinkan adanya lalat yang hinggap, serta talenan dan pisau sehabis digunakan tidak dicuci.

Tempat pengelohan minuman (TPM) mempunyai potensi yang cukup besar untuk menyebabkan gangguan kesehatan atau penyakit bahkan keracunan akibat dari makanan yang dihasilkannya. Salah satu syarat kesehatan TPM yang penting dan mempengaruhi kualitas higiene sanitasi makanan tersebut adalah faktor lokasi dan bangunan TPM. Lokasi dan bangunan yang tidak memenuhi syarat kesehatan akan memudahkan terjadinya kontaminasi makanan oleh mikroorganisme seperti bakteri, jamur, virus dan parasit serta bahan-bahan kimia yang dapat menimbukan risiko terhadap kesehatan.

4. Hubungan Sanitasi Penyimpanan Bahan Dengan Kandungan Bakteriologis

Berdasarkan hasil observasi ditemukan sebanyak $74 \%$ pedagang menggunakan buah tidak dalam kondisi segar dan berkualitas baik hal ini dikarenakan para pedagang membeli buah dalam stok banyak yang mana akan digunakan untuk beberapa hari kedepan.

Pada dasarnya dalam memilih bahan makanan diharapkan memilih bahan makanan yang masih segar, utuh, tidak retak atau pecah, tidak terdapat kotoran, dan tidak berulat. Adapun ciri - ciri buah - buahan yang baik yaitu: keadaan fisiknya baik, isinya penuh, kulit utuh, tidak rusak atau kotor; isi masih terbungkus kulit dengan baik, warna sesuai dengan bawaannya, tidak ada warna tambahan, warna buatan (karbitan), dan warna lain selain warna buah; tidak berbau busuk, bau asam / basi atau bau yang tidak segar lainnya; tidak ada cairan getah lain selain getah aslinya.

\section{Kesimpulandan Saran}

\section{Kesimpulan}

a. Ada hubungan higiene penjamah dengan kandungan bakteriologis pada minuman yang dijual di sepanjang Pantai Losari.

b. Ada hubungan kebersihan peralatan dengan kandungan bakteriologis pada minuman yang dijual di sepanjang Pantai Losari.

c. Ada hubungan tempat pengolahan minuman dengan kandungan bakteriologis pada minuman yang dijual di sepanjang Pantai Losari.

d. Ada hubungan penyimpanan bahan dengan kandungan bakteriologis pada minuman yang dijual di sepanjang Pantai Losari.

\section{Saran}

a. Bagi pedagang kaki lima, hendaknya lebih memperhatikan higiene personal seperti kebersihan anggota badan dan kelengkapan APD (Alat Pelindung Diri) yang seharusnya digunakan, agar dapat meminimalisir masuknya kontaminan keminuman.

b. Hendaknya para pedagang kaki lima, lebih memperhatikan kondisi sarana sanitasi yang meliputi kebersihan peralatan, sanitai penyimpanan bahan maupun sanitasi tempat pengolahan minuman, karena kondisi sanitasi yang buruk dapat menjadi pemicu adanya bakteri Coliform dalam jus buah.

\section{DAFTAR PUSTAKA}

Agustina. 2014. Gambaran Pengetahuan,Sikap dan Tindakan Higiene Sanitasi Pedagang Makanan Jajanan di Sekolah Dasar Cipinang Besar Utara Kota Madya Jakarta Timur. Skripsi. Jurusan Kesehatan Masyarakat. Universitas Islam Negeri Syarif Hidayatullah Jakarta (online) http://www.repository.uinjkt.ac.id Diakses 12 Desember 2017 
Jurnal Sulolipu : Media Komunikasi Sivitas Akademika dan Masyarakat

Vol. 19 No.12019

e-issn : 2622-6960, p-issn : 0854-624X

Ayuningtyas, N.V. 2012. Hubungan Frekuensi Jajan Anak dengan Kejadian Diare Akut pada Anak Sekolah Dasar di SDN Sukatani 4 dan SDN Sukatani 7, Kelurahan Sukatani, Depok Tahun 2012. Skripsi. Universitas Indonesia. Jakarta (online) http://www.repository.ui.ac.id Diakses 5 Desember 2017

Badan Pengawas Obat dan Makanan (BPOM). 2009. Penetapan Batas Cemaran Mikroba dan Kimia dalam Makanan. Jakarta: Badan Pengawas Obat dan Makanan

Dyah, dkk. 2015. Hubungan Higiene Penjamah dengan Keberadaan Bakteri Escherichia Coli Pada Minuman Jus Buah di Tembalang, 14 (1) : 14-15 (online) http://www.repository.unnes.ac.id Diakses 22 Desember 2017

Fatimah, dkk. 2017. Analisis Coliform Pada Minuman Es Dawet yang Dijual Di Malioboro Yogyakarta. 76 (online) http://www.repository.uajy.ac.id Diakses 23 November 2017

Hisianti A. Purnawijayanti. 2006.Sanitasi Higiene Dan Keselamatan Kerja Dalam Pengolahan Makanan. Yogyakarta: Kanisius

H.J.Mukono. 2004. Prinsip Dasar Kesehatan Lingkungan dalan Agustina, 2011 Hubungan Antara Higiene Penjamah dan Sanitasi Makanan dengan Keberadaan Bakteri Escherichia Coli. Skripsi. Jurusan Kesehatan IImu Masyarakat. Universitas Negeri Semarang: 14-15 (online) http://www.repository.unnes.ac.id Diakses 22 Desember 2017

K.A. Buckle, dkk. 2000. Ilmu Pangan.(ab.Hari Purnomo) Jakarta: UIP

Nur Laila, Agustina 2013. Hubungan Antara Higiene Penjamah Dan Sanitasi Makanan Dengan Keberadaan Bakteri Escherichia coli. Skripsi. Jurusan IImu Kesehatan Masyarakat. Universitas Negeri Semarang. Semarang. (online) http://www.repository.unnes.ac.id Diakses 22 Desember 2017

Moertjipto, 1993. Makanan: Wujud, Variasi dan Fungsinya Serta Cara Penyajiannya pada Orang Jawa Daerah Istimewa Yogyakarta. Jakarta: Departemen Pendidikan dan Kebudayaan, Direktorat Jenderal Kebudayaan, Direktorat Sejarah dan Nilai Tradisional, Proyek Penelitian, Pengkajian dan Pembinaan Nilai-Nilai Budaya

Nani Rahmani dan Sarah Handayani, 2015. Kontaminasi Bakteri Escherichia Coli Pada Makanan Dan Minuman Penjual Jajanan di Lingkungan Pendidikan Muhammdiyah Limau, Jakarta Selatan: 27 (online) http://www.repository.uajy.ac.id Diakses 23 November 2017

P.J. Fellows. 2016. Teknologi Pengolahan Pangan Prinsip dan Praktik, $72-73$ Jakarta: Buku Kedokteran EGC

Purwiyatno, Hariyadi, dkk. 2009. Petunjuk Sederhana Memproduksi Pangan Yang Aman, 54, Jakarta: Dian Rakyat

Rahmani, Nani, dkk. 2016. Kontaminasi Bakteri Escherichia Coli Dan Minuman Penjual Jajanan di Lingkungan Pendidikan Muhammadiyah Limau. Jakarta Selatan. 1 (1) : 25-27 (online) http://www.repository.uajy.ac.id Diakses 23 November 2017

Republik Indonesia. 2012. Kumpulan Modul Kursus Higiene Sanitasi Makanan dan Minuman Sub: Direktorat Higiene Sanitasi Pangan Diretktorat Penyehatan Lingkungan Direktorat Jenderal PP dan PL. Jakarta

Republik Indonesia. 2003. Keputusan Menteri Kesehatan RI Nomor 942/Menkes/SK/VII/2003 tentang Pedoman Pesyaratan Higiene Sanitasi Makanan Jajanan.

Republik Indonesia. 2017. Profil Kesehatan Indonesia 2016. Jakarta: Kementerian Kesehatan Republik 
Jurnal Sulolipu : Media Komunikasi Sivitas Akademika dan Masyarakat

Vol. 19 No.12019

e-issn : 2622-6960, p-issn : 0854-624X

Indonesia.

Rizsa Puspita. 2015. Upaya Penjamah Makanan Dalam Menjaga Kualitas Ditinjau Dari Aspek Food Safety Pada Warung Makan Di Sekitar Universitas Negeri Semarang. Skripsi. Jurusan Ilmu Kesehatan Masyarakat Universitas Negeri Semarang. Semarang. (online) http://www.repository.unnes.ac.id Diakses 12 Desember 2017

Republik Indonesia. 2003. Keputusan Menteri Kesehatan Republik Indonesia nomor 942/MENKES/SK/VII/2003 tentang Pedoman Higiene Sanitasi Makanan Jajanan

Siti, Fathonah. 2005. Higiene dan Sanitasi Makanan. Semarang: Unnes Press

Skipton, S.O. 2014. Drinking Water: Bacteria. Neb Guide. University of Nebraska-Lincoln Extenstion. (Diakses pada 28 Desember 2017)

Sofiana, Erna. 2012. Hubungan Higiene dan Sanitasi dengan Kontaminasi Escherichia coli Pada Jajanan di Sekolah Dasar Kecamatan Tapos Depok. Skripsi. Jurusan Kesehatan Masyarakat, Universitas Indonesia. 24 (online) http://www.repository.ui.ac.id Diakses 2 Desember 2017

Sucipto, Dani Cecep. 2015. Keamanan Pangan Untuk Kesehatan Manusia. Jatirejo: Gosyen Publishing

Standar Nasional Indonesia (SNI). 2009. Batas Maksimum Cemaran Mikroba Dalam Pangan. Jakarta : Standar Nasional Indonesia

Treesna Wulandari, dkk. 2017. Analisis Bakteriologi Sample Minuman Yang Diambil Dari Area Sekitar Kampus II Sekolah Tinggi IImu Kesehatan Bali. (2):224-230. (online) http://ojs.unud.ac.id Diakses 10 Desember 2017

Wahyuni dan Inayah, 2014. Panduan Praktikum Mikrobiologi. Makassar: Politeknik Jurusan Kesehatan Lingkungan 